\title{
Microbial formulation and growth of cereals, pulses, oilseeds and vegetable crops
}

Kalyani Naik, Snehasish Mishra*, Haragobinda Srichandan, Puneet Kumar Singh and Abhishek Choudhary

\begin{abstract}
Effective microbes (EM) are the coexisting naturally occurring useful microbes applied as inoculant to enhance the beneficial microflora of the soil ecosystem to facilitate agricultural production. The participating microbial consortium includes lactic acid and photosynthetic bacteria, actinomycetes, fermenting fungi, and yeast, among others. These microbes are physiologically well-matched and coexist in a provided medium. EM formulation could be applied to a target crop in the most appropriate manner and form, and is easy to handle. It could be applied in several manners, as soil application, foliar application and as seed treatment. Microbial formulation in agricultural practices for enhancing productivity is sustainable and eco-friendly approach. When applied, EM formulations reportedly have positive effect on several crop growth parameters. It enhances the productivity, biomass accumulation, photosynthetic efficiency, and antioxidative response to abiotic stress in rice. EM formulations reportedly augment the trace elements contents, root and shoot weight, nodulation and pod yield in rajmah, while it boosts the root and shoot weight, nodulation and seed yields in bean, and drought and virus tolerance, shoot weight, pod number and biomass in soybean. Reportedly, formulated EM perks up the chlorophyll, N, P, carbohydrate and protein contents in sunflower, whereas it stimulates the root and shoot growth, leaf number, fungal disease resistance in groundnut. It could lead to an improved root growth, plant height, chlorophyll content, pod yield, fungal disease resistance, $\mathrm{Cr}$-resistance and pest resistance in okra. This review compiles and provides critical insight to the effects of EM formulations on various crops, particularly the cereals (rice), pulses (rajmah, bean and soybean), oilseeds (sunflower and groundnut) and vegetable (okra).
\end{abstract}

Keywords: Agriculture, Effective microbe, EM formulation, Environmental probiotics, Microbe-microbe interaction, Plant-microbe interaction

\section{Introduction}

Healthy soil ecology entails the ability of soil to save the flora against soil-borne pathogenic microbes and parasites. Soil ecosystem balances the relationship between the pathogenic and numerous useful microbes working together in synergy [1]. The obliging saprobic microflora ferments and decomposes the soil organic material and supplement to the nutrient pool for the plants, while additionally augmenting the soil particles helping in its

\footnotetext{
* Correspondence: snehasish.mishra@gmail.com

Biogas Developmnt and Training Centre, Kalinga Institute of Industrial Technology, Bhubaneswar 751 024, India
}

moisture and nutrient holding capacities [1]. Applying animal manures and liquid compost (composed of plant growth constituents and useful microbes) to the soil is a scientific approach towards sustainable farming. It could be used to improve soil quality, promote plant growth and protect the crops from pathogenies [2]. Although an integral component of crop ecosystem, the active soil microbes are little recognised in agricultural management strategies, and their role needs to be augmented further [3].

Continuous and indiscriminate use of chemicals poses a negative impact on soil, environment, and ultimately

(C) The Author(s). 2020 Open Access This article is licensed under a Creative Commons Attribution 4.0 International License, which permits use, sharing, adaptation, distribution and reproduction in any medium or format, as long as you give appropriate credit to the original author(s) and the source, provide a link to the Creative Commons licence, and indicate if changes were made. The images or other third party material in this article are included in the article's Creative Commons licence, unless indicated otherwise in a credit line to the material. If material is not included in the article's Creative Commons licence and your intended use is not permitted by statutory regulation or exceeds the permitted use, you will need to obtain permission directly from the copyright holder. To view a copy of this licence, visit http://creativecommons.org/licenses/by/4.0/. 
human health, in the same sequence. Use of chemical fertilisers indiscriminately leads to soil pollution gradually deteriorating the soil fertility. Although productivity increased appreciably to feed the starving population with the onset of green revolution (in early 70s), the use of chemical fertilisers and pesticides glorified then had an obvious long-term adverse effect [4]. Since then, the synthetic chemicals have taken the front seat in current global agriculture. Excess accumulation of such chemicals in crops bioaccumulates and biomagnifies along the food chain thereby adversely affecting human and animal health. Chemical run-offs from agri-systems when flooded further add to the awe. So, concerted scientific investigations to utilize agricultural resources efficiently and enhance productivity through biological means instead of chemicals are underway. Applying organic practices along with effective microbes (EMs) for yield enhancement on a sustainable basis is a promising approach. Nutrients recycling becomes efficient through this by saprobes, and the urgency for chemical fertiliser dwindles [4-6].

Using microbes solely or in a consortium could enhance the productivity of most farming systems significantly as the microbes and plants have been evolutionarily interacting in nature $[7,8]$. Among various microbial communities active in agricultural faming systems, fungi, bacteria, actinomycetes and yeasts have been recommended as potential EMs [1]. Applying composts and animal manure in an agricultural system along with EMs (as EM formulations) to the soil environment promotes plant growth. As the EMs persist in the soil environment for a long time, their beneficial effects in the growth and development of the crops is manifested better $[9,10]$.

The sludge and organic wastes treated by the EMs could be applied as biofertilizer, wherein the EM participants as well as the essential nutrients could be healthy inputs for crop growth. The beneficial bacteria and fungi present in the biofertilizers help improve chemical and biological characteristics of the soil thereby ensuring agricultural productivity $[11,12]$. In biofertilizer, various microbial communities, viz., fungi, bacteria, actinomycetes and yeasts, are used as inoculant and they majorly promote plant growth through activities like fixing $\mathrm{N}_{2}$, phosphate and potassium solubilisation, exopolysaccharides secretion, biocontrol agent, organic matter decomposition, and siderophores production [3, 13]. The various mechanisms of action performed by the EMs promoting plant growth and development are graphically presented in Fig. 1. Diazotrophs like Rhizobium sp.

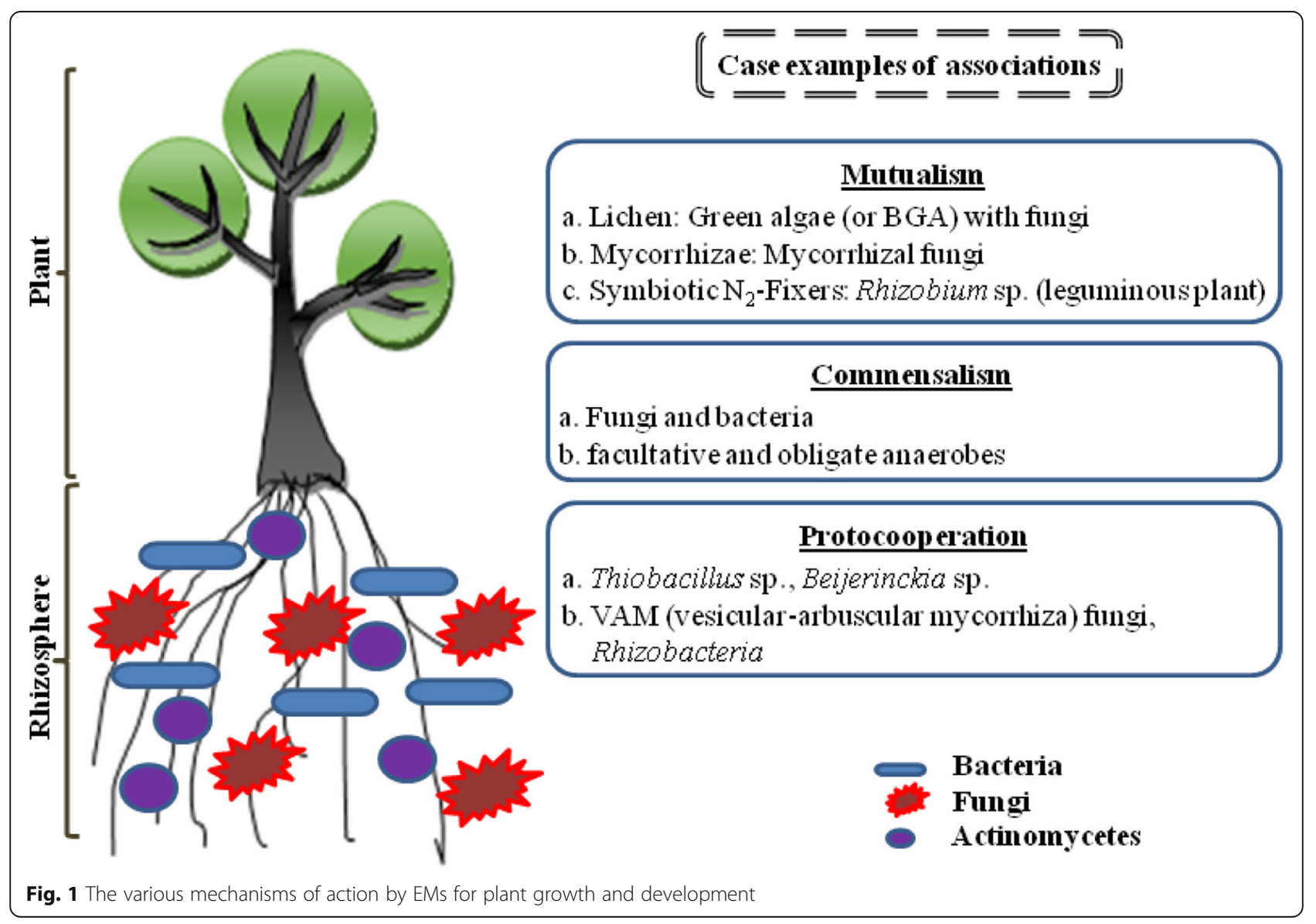


and Bradyrhizobium sp. are the major $\mathrm{N}_{2}$-fixers [14]. Azospirillum, a free-living $\mathrm{N}_{2}$-fixer reportedly enhances the growth in non-leguminous crops [15]. Pseudomonas putida and Pseudomonas fluorescens are not only good biocontrol agents but also stimulate crop growth through biological $\mathrm{N}_{2}$-fixation and by enticing hormonal secretion for plant growth [16]. Azotobacter and Azospirillum application as EMs reportedly enhance strawberry production $[17,18]$. Phosphorus, which is the key nutrient in soil and is present in complex unavailable forms, is made available for the plant through the activity of phosphate solubilising microbes. Han and Lee [19] reported the benefits of phosphate solubilising bacteria $\mathrm{Ba}$ cillus megaterium and potassium solubilising bacteria Bacillus mucilaginosus in enhanced nutrient uptake by eggplant in nutrient-limited soil. Coinoculating two or more microbes might improve the yield and growth as compared to a single one due to the added benefits of their concerted efforts [19].

Photosynthetic and lactic acid bacteria, fermentative fungi, actinomycetes and yeasts or their combinations are a part of a formulated EM [20-22]. EMs as environmental probiotics are added to the prebiotic that result in formulated EM. In a formulated EM, the biotic (as environmental probiotic) and abiotic (as the prebiotic) are two important ingredients, wherein the microbes act as a probiotic and the carbon and other nutrient sources act as prebiotics. Kato et al. [20] and Raja and Bharani [22] collected beneficial microbes from nature and formulated the EM using lactic acid bacteria (Lactobacillus plantarum, Lactobacillus casei, Streptoccus lactis), photosynthetic bacteria (Rhodopseudomonas palustris, Rhodobacter sphaeroides), yeasts (Saccharomyces cerevisiae, Candida utilis), actinomycetes (Streptomyces albus, S. griseus), and fungi (Aspergillus oryzae, Mucor hiemalis) [20, 22]. Formulated EM application along with organic fertiliser enhances the growth, nutrient uptake and grain yield of sweet corn as compared to chemical fertilisers [20]. As wood waste residue provides a suitable environment for the EM to thrive, and a high quality compost could be produced, EM formulation could be used in industrial wood waste management [21].

\section{Impact of EMs on various crops}

EM formulations are available commercially as well as prepared by researchers themselves for pilot- and fieldscale studies. The detail information of some commercially available as well as self-made EM formulations, along with the participating microbes on plant growth promotion is furnished in Table 1.

Commercial liquid formulation EM-1 containing lactic acid bacteria (Lactobacillus plantarum), yeast (Candida utilis), and actinomycetes (Streptomyces albus) decomposes fruits and vegetables refuge and the resultant compost performs better in terms of increased leaf surface area, total leaves, total chlorophyll content, shoot length, plant height, branches and foliage count [22]. Another EM formulation composed of Bacillus sp. Pseudomonas aeruginosa, Streptomyces sp. was used in seed treatment of sunflower for improving crop performance, that also help in preventing sunflower from necrosis disease [31]. EM culture consisting of photosynthetic bacteria (Rhodopseudomonas palustris and Rhodobacter sphaeroides), lactic acid bacteria (Lactobacillus plantarum, Lactobacillus casei and Streptococcus lactis), yeasts (Sacharomyces sp.), and actinomycetes (Streptomyces sp.) reportedly produces bioactive substances including enzymes, controls soil-borne diseases and accelerates lignin decomposition in the soil [32]. EMs are mutually compatible, and live for an extended period [33]. EMs could suppress the growth and activity of the indigenous putrefactive microbes that add to malodours in plants [34]. Problems in handling of organic urban waste like bad odour, fly population control and pathogenic microbes' devaluation in piling of waste could be prevented by applying formulated EMs [34].

EM Application has been successfully tried on vegetable crops in New Zealand and Sri Lanka, herbage grasses in Holland and Austria, and apples in Japan. Bokashi (nutrients and EM-enriched compost) was applied in these studies, that increased the yield over a period of time [35]. As the first solid form of EM formulation for agricultural applications, Bokashi compost was prepared using organic refuge like saw-dust mixed with nitrogen-rich materials like rice husk, corn bran, wheat bran, fish meal and oil cake [36]. Bokashi base material is normally prepared by mixing molasses with water, followed by the addition of EM consortia. The resultant mixture is further mixed with dry ingredients (mixture of rice bran, oil cake, fish meal, etc.). The final mixture is allowed to ferment in airtight container, for 4-5 (in summer) to 7-8 (in winter) days under tropical conditions. After fermentation, a sweet and fermented odour suggests that Bokashi is ready for application. Bokashi reportedly facilitates nutrient release from soil, improves soil carbon mineralisation, and enhances the soil properties. It also increases the photosynthesis and protein activity in crops, increases crop resistance to water stress, facilitates spreading of the roots, and suppresses the pests and plant diseases in agricultural practices [35-37].

Liquid EM formulations have been used in agricultural practice extensively. Foliar application of EM formulation was compared with chemical fertilisers on onion, watermelon, garlic and tomato, and the yields were higher in EM application. Foliar application of EMs evades various biotic and abiotic factors and other limitations in soil microenvironment, thereby increasing the yield and quality of crops, fruits and vegetables [24]. 


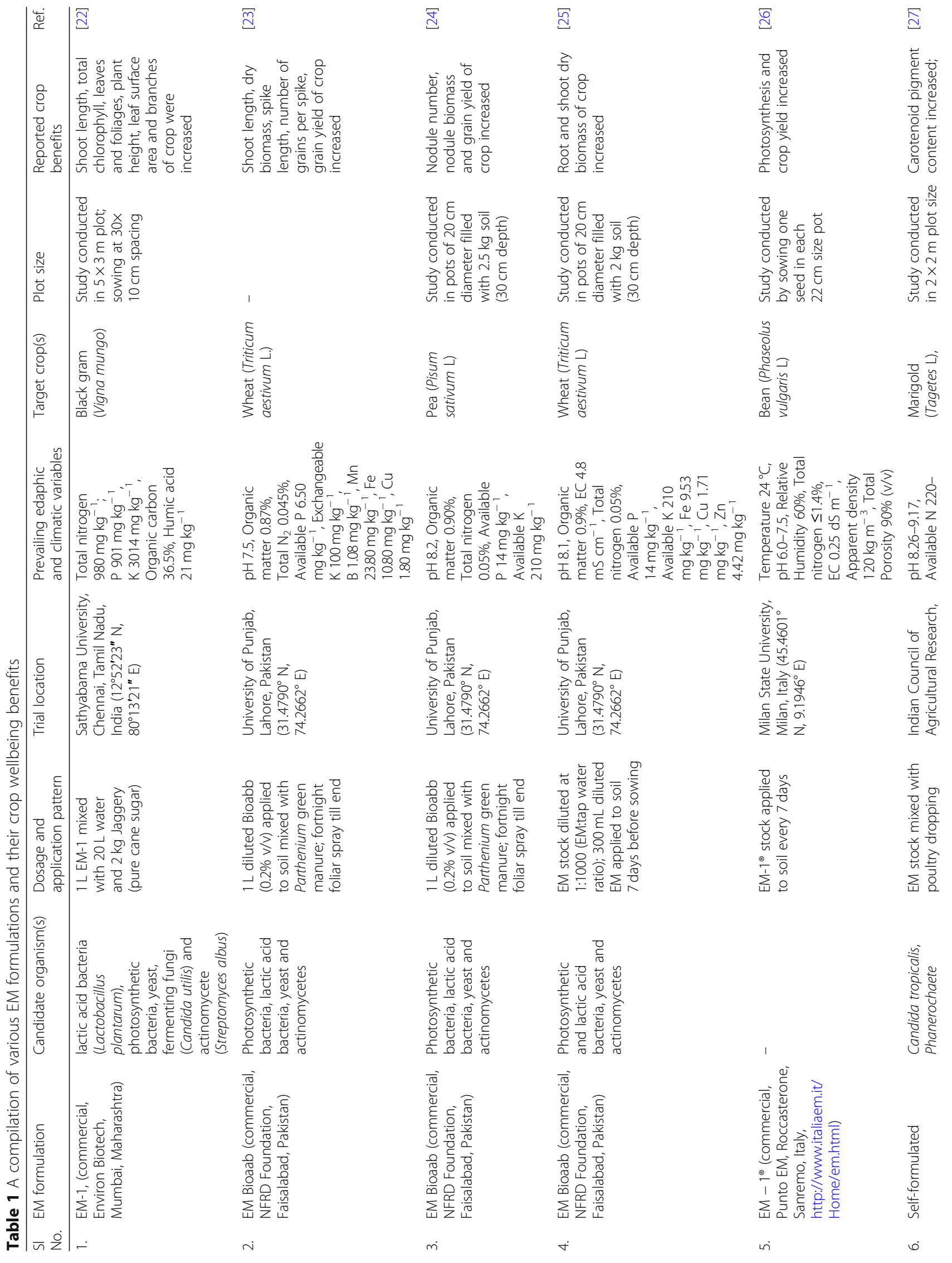




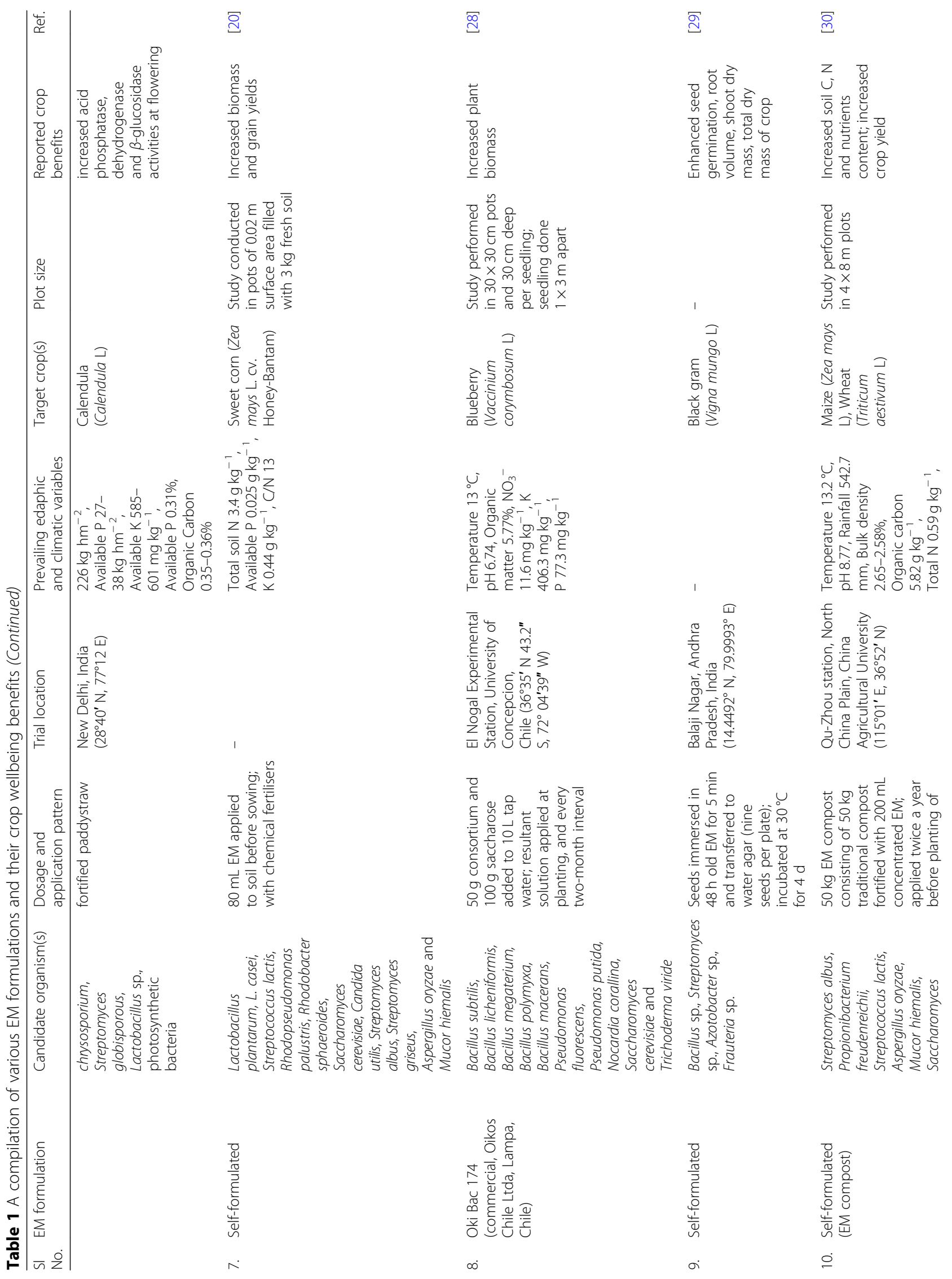




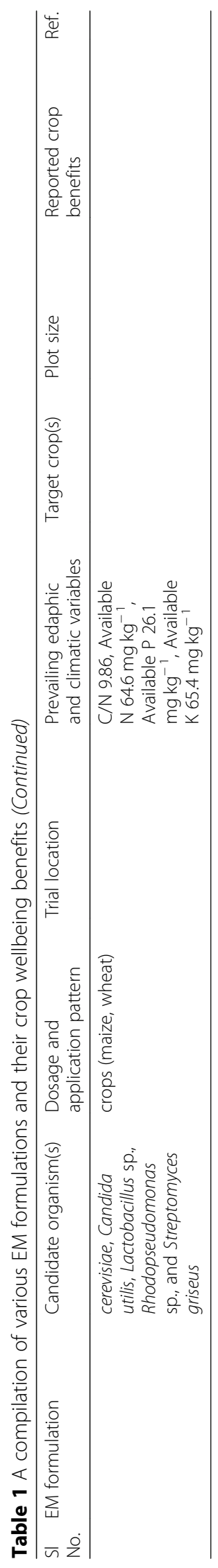


Foliar application alongside NPK amendment of soil resulted in $120 \%$ grain yield, $217 \%$ in nodular number and $167 \%$ in nodular biomass, while an additional green manure amendment increased the grain yield by $145 \%$ [25]. Compared to the control, foliar spray of EM formulation at 15-d interval for three times gave higher pod yields in okra [38].

\section{Role of EMs in agro-ecosystem}

Plant growth by EMs may proceed either through direct or indirect action [39]. Direct action refers to soil amelioration, production of plant growth substances, soil fertility improvement by mobilising soil mineral components, $\mathrm{N}_{2}$-fixation, phosphate and minerals solubilization, phytohormones production, and deamenase activity. The indirect action, on the other hand, refers to the biocontrol activities that inactivate or kill plant pathogens thereby providing a healthy cropping environment.

Plant growth-promoting rhizobacteria (PGPR), plant growth-promoting bacteria (PGPB) and vesiculararbuscular mycorrhizae (AMF) fungi are various growth promoting microbes (PGPM). PGPR provides a favorable environment for plant-microbe interaction. $\mathrm{N}_{2}$-fixers like Rhizobium, Sinorhizobium, Bradyrhizobium, Azorhizobium, Mesorhizobium, Allorhizobium are potential mutually-benefitting plant growth promoting endosymbionts [39]. Genera like Azospirillum, Enterobacter, Klebsiella and Pseudomonas proficiently colonize root surfaces and fix nitrogen [40]. PGPB like Pseudomonas fluorescens and Bacillus subtilis induce PGPRs to produce plant growth-promoting substances [41]. As a classic case of symbiosis, the amino acids, carbohydrates, active enzymes and organic acids secreted by the plant roots are used by the EMs, and the EMs secrete amino acids, various vitamins, nucleic acids and hormones for the plant in return.

ACC (1-aminocyclopropane-1-carboxylic acid) deaminase producing microbes like actinomycetes would takeup and metabolise ACC to $\alpha$-ketoglutarate and $\mathrm{NH}_{3}$, thereby decreasing ethylene concentration (excess concentration adversely affects growth) in plant. These actinomycetes individually or as coinoculants reportedly fix $\mathrm{N}_{2}$, solubilize phosphate, and produce siderophore in sugarcane [42]. Soil actinomycetes could produce numerous antibiotics and extracellular enzymes that inhibit plant pathogens. Numerous actinomycetes protect plants against diseases [43]. Soil salinity particularly in coastal belts is a challenge for crop growth and wellbeing [44], and Enterobacter sp. UPMR18 reportedly enables okra plant to withstand salt stress [45]. Okra plant has better germination percentage and higher leaf chlorophyll contents by rhizospheric EM symbionts [42].

\section{Interactive role of participating microbes in a formulated EM}

Coexistence of various microbial species is a prerequisite in a formulated EM. Microbial interactions occur through secondary metabolites, siderophores, quorum sensing system, biofilm formation, and cellular transduction signalling [46]. The ultimate interaction unit is the gene expressed in each organism in response to an environmental (biotic or abiotic) stimulus that is responsible for the production of molecules for microbial interactions [46]. The participating microbes in an EM formulation may interact with each other through mutualism, commensalism, and protocooperation. A case example of mutualism is the blue green algae and fungus where they exchange nutrition among one another [46]. The algae get protection from environmental stress by the surrounded fungal hyphae which in turn gets carbon that is fixed by algae (algal photosynthesis). Similarly, a commensalism association is seen in cellulose and lignin degrading fungi to glucose and organic acids that are utilised by bacteria further [47].

Protocooperation is a mutualism in which both the microbial partners benefit from each other without depending on each other for survival [48]. Here, favor is extended by one organism to its associate by providing carbonaceous products. Nutritional association for several vitamins, amino acids and purines is observed between bacteria and fungi in terrestrial ecosystems. Nutritional protocooperation may be formed between various bacteria and fungi in which various vitamins, amino and purine are produced by certain microbes that could be utilised by the partner microbes. Proteous vulgaris and Bacillus polymyxa may form nutritional protocooperation for nicotinic acid and biotin, respectively [49]. While formulating an EM, other various interactions of little relevance are antagonism, competition, parasitism, and predation. The survival of one microbe may be at stake (due to the inhibitory or lytic effect of the other partner) when these microbial associations are negative.

\section{Plant-microbe interaction}

Plants constantly interact with an enormous soil microflora (Fig. 2). Ecological interactions like mutualism, commensalism, amensalism, protocooperation and antagonism might contribute to the overall soil health and plant wellbeing [13, 46, 50]. Lichen is an association of green or cyanobacterial algae with fungus (ascomycetes). The alga is saved from environmental stresses by the fungal hyphae, while the fungus obtains nutrients and oxygen from the photosynthetic algae. Similarly, the leguminous plant acquires readily available fixed nitrogen source from Rhizobium, and the Rhizobium is protected by the leguminous plant from environmental stress in 


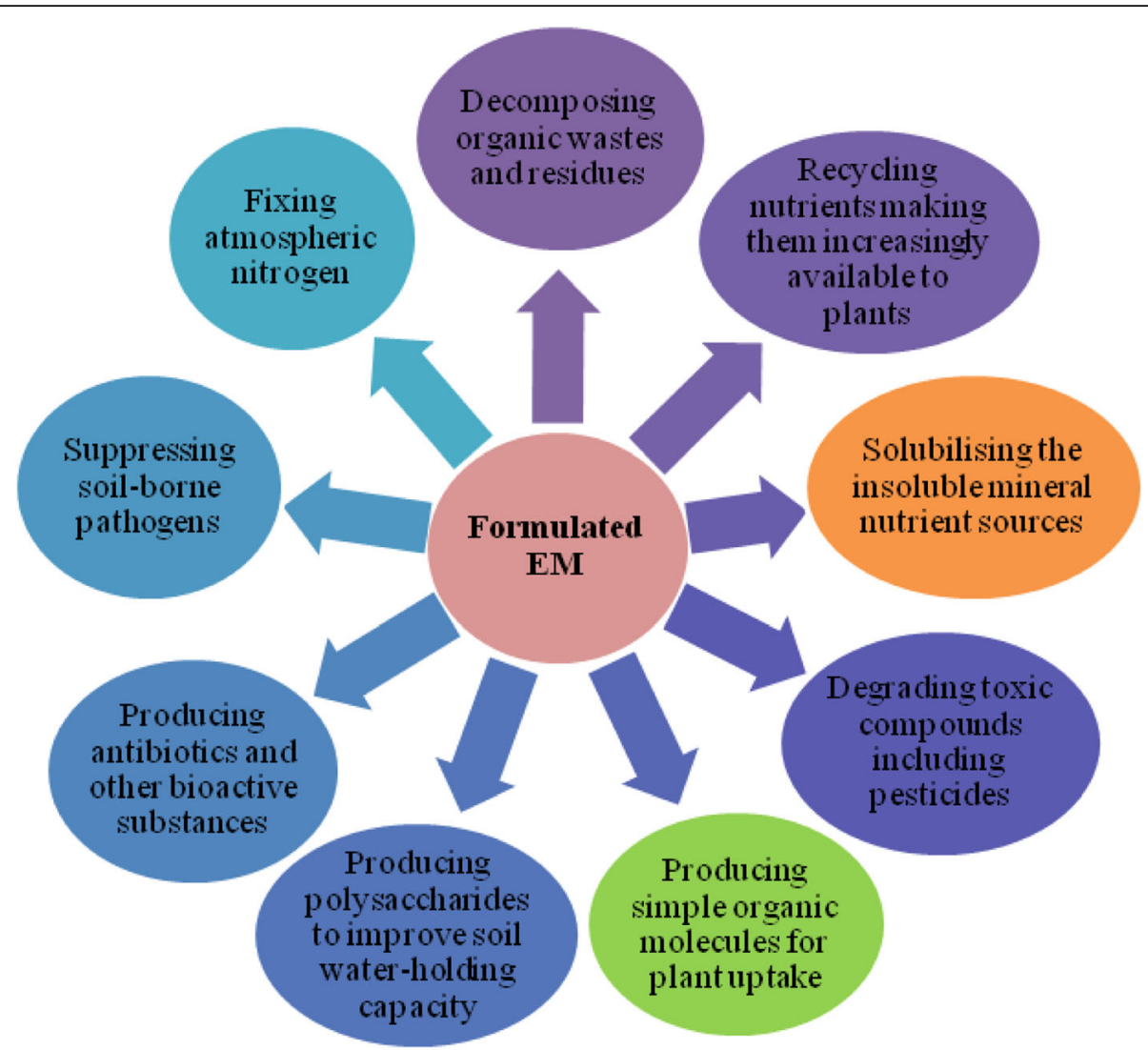

Fig. 2 Microbe-microbe and plant-microbe interactions for sustainable agriculture

return. Frankia (an actinomycete) forms a symbiotic association with Alnus and Casuarina (non-legume plants) supplementing them with the fixed nitrogen and obtains organic nutrients in return. Mycorrhizal fungi associate with the plant roots and obtain carbohydrates, while it increases the surface area for water, $\mathrm{N}, \mathrm{P}$ and inorganic nutrients to be absorbed by plants in return. Endomycorrhizal symbioses help plant withstand environmental stress and enhance the soil structure by forming hydrostable aggregates [51, 52].

Amensalistic association suppresses the growth of one partner by the other through toxins (like antibiotics) production. Here, a soil pathogenic microbe is inhibited by amensal partner where the later remains unaffected thereby benefitting crop growth. Some amensals also release harmful gases like hydrogen cyanide $(\mathrm{HCN})$, ethylene, methane, nitrite, sulphides and other volatile compounds of sulphur [52]. In agriculture, synergism is seen between VAM fungus-legume plants and Rhizobium. In this association, nitrogen is fixed by Rhizobium for the plants to uptake the fixed nitrogen. Phosphorus uptake by plant is also elevated which results in increased crop yields and improved soil fertility.

Antagonism association is the most common in nature which is governed essentially by antibiotic production.
Here, an organism directly or indirectly inhibits the activities of the other, e.g., the soil Bacillus sp., Pseudomonas fluorescens and Streptomyces sp. produce antibacterial and antifungal antibiotics that help suppress various plant pathogens. Thiobacillus sp. reduces the soil $\mathrm{pH}$ up to 2.0 thereby restricting the growth of $\mathrm{pH}$-sensitive microbial species. In lichen, the $\mathrm{O}_{2}$ produced by algae prevents anaerobic microbes from colonisation, while the cyanide produced by fungi is toxic to numerous other microbes [13, 46, 50,52].

\section{Microbial (EM) formulation}

\section{Probiotics (EMs)}

As mentioned earlier, the EMs predominantly consist of physiologically compatible lactic acid and photosynthetic bacteria, yeasts, fermenting fungi and actinomycetes $[10$, $53,54]$. Adding photosynthetic bacteria to the soil provides a heathy environment for growth of other EMs. VAM fungi increases the soil phosphate solubility and coexist with the $\mathrm{N}_{2}$-fixing Azotobacter and Rhizobium. Lactic acid bacteria secrete lactic acid that sterilizes the soil, and suppresses the thriving harmful microbes (like Fusarium) and nematodes, and stimulates the decomposition of lignocellulosic organic materials in soil [55]. Bioactive substances like phytohormones and enzymes 
produced by fungi help promote active cell/root division, while providing useful substrates for EMs, viz., lactic acid bacteria and actinomycetes [56]. Fermenting fungi help decompose organic matters and rapidly producing alcohol, esters and antimicrobial substances that help suppress harmful insects and maggots [57]. Actinomycetes are other critical antimicrobial producers from amino acids secreted by photosynthates that would suppress the harmful soil microbes. Thus, various EM species complement each other and form mutuallybeneficial relationships in the soil [57]. EMs enhance the quality of soil profile and thereby facilitate crop growth and development [58].

\section{Prebiotic/carriers for microbial inoculants}

Microbial formulation is a carrier-based preparation to provide microbes with better survival for longer duration. Prebiotic carriers provide the desired nutrients to augment the EMs. EMs are formulated with the prebiotic to facilitate storage, commercialisation and easy field application. The affordability and availability are the two significant factors while selecting a carrier.

Few of the desirable characteristics of a quality carrier are lump-free material that is easy to process, moisture absorption capacity, ease of sterilization, cost efficient, plentily available and a good inherent $\mathrm{pH}$ buffering capacity. While dry formulations are produced using solid carriers like soil (peat, coal, clay, and inorganics), organic (composts, soybean meal, wheat bran, and sawdust), or inert (vermiculite, perlite, kaolin, bentonite, and silicates) materials, liquid formulations can be prepared using mineral oil, organic oils, oil-in-water suspensions, molasses, humic acid, and landfill leachates [59, 60]. These have been detailed in Table 2 .

\section{Solid carrier base}

A formulation can be prepared by mixing compatible beneficial microbes with the prebiotic. Microbial viability and shelf-life in formulation are important in formulation. Majority of formulations use charcoal, talc or other inert carrier material. Pseudomonas fluorescens formulation was mixed with talc and $1 \%$ carboxymethyl cellulose and used against leaf disease. Alginate-base formulation of Bacillus subtilis and Pseudomonas corrugata was easy to prepare and dry, and could be stored up to 3 years [68].

Compost is a good nutrient natural carrier for the EMs. It is biodegradable and non-polluting, usually processed from abundant natural waste materials. While supporting soil microbes to survive, it also facilitates plant growth. Composting has been established as one of the low-cost alternatives to minimize the volume of solid waste disposed of to the environment $[59,69]$. This form of transformation of various organic wastes into compost is safe and economical [70,71]. By converting the biowastes into composts, the nutrients in the waste can be utilized better creating a zero-waste system [71]. The converted compost would contain a substantial amount of EMs that are helpful for plant growth and yield.

Talc and charcoal based formulations of Bacillus sp. increases the growth of mung bean and rice [72]. Bacillus sp. shows antagonistic effects against various phytopathogens, including Rhizoctonia solani (ITCC-186) and Fusarium oxysporum (ITCC-578). Likewise, alginatebase formulation of Bacillus subtilis and Pseudomonas corrugata (PGPRs) reportedly benefit the crops [68]. A solid base Piriformospora indica (root endophyte) formulation as bioinoculant enhances the growth of Phaseolus vulgaris L. [73]. This solid base formulation also increases the adaptability of Phaseolus vulgaris L. to greenhouse conditions.

\section{Liquid carrier base}

The EM could be formulated using aqueous, oil or polymer liquid base. The liquid base contains nutrients, cellular protection and additives to promote survival after seed or soil applications [74]. Such prebiotics in EM formulation are glycerol, vermicompost wash, indole acetic acid, and malic acid. Such a PGPM formulation of Bacillus licheniformis, Bacillus sp., Pseudomonas aeruginosa, Streptomyces fradiae shows good microbial survival even after 120 -d storage period [74, 75]. The seed germination and plant height increase by using liquid formulation treatment in sunflower $[74,75]$.

\section{Means to apply EM formulations}

The various ways to apply agricultural EM formulations include applying it directly into the soil (soil application), spraying it on leaves (foliar application), and soaking the seeds in it prior to sowing [58]. Seeds are soaked in $0.1 \%$ EM suspension for half an hour (for smaller seeds) or up to 4-6 h (for larger seeds). The seeds are carefully semidried before sowing ensuring that they do not clump.

In foliar application, the crops benefit from the EM through the foliage. Foliar spray is effective when applied in the evening or early morning. A dilution of 1:1000 with water is often recommended [58]. Foliar application of EM with soil application of fermented plant extract enhances the yields of cucumber and reduces the instance of pickle worm infection [56]. Foliar application of $0.1 \%$ EM improves the quality and enhances the yield of tea (by 25\%), cabbage (by 14\%), and sugar corn (by 12.5\%) [32]. The impact of foliar-applied EM and seed treatment on groundnut, along with $0.1,0.5$ and $1.0 \%(\mathrm{v} /$ v) EM concentrations foliar application on garlic, onion, tomato and watermelon at one- and two-week intervals are effective [32]. 


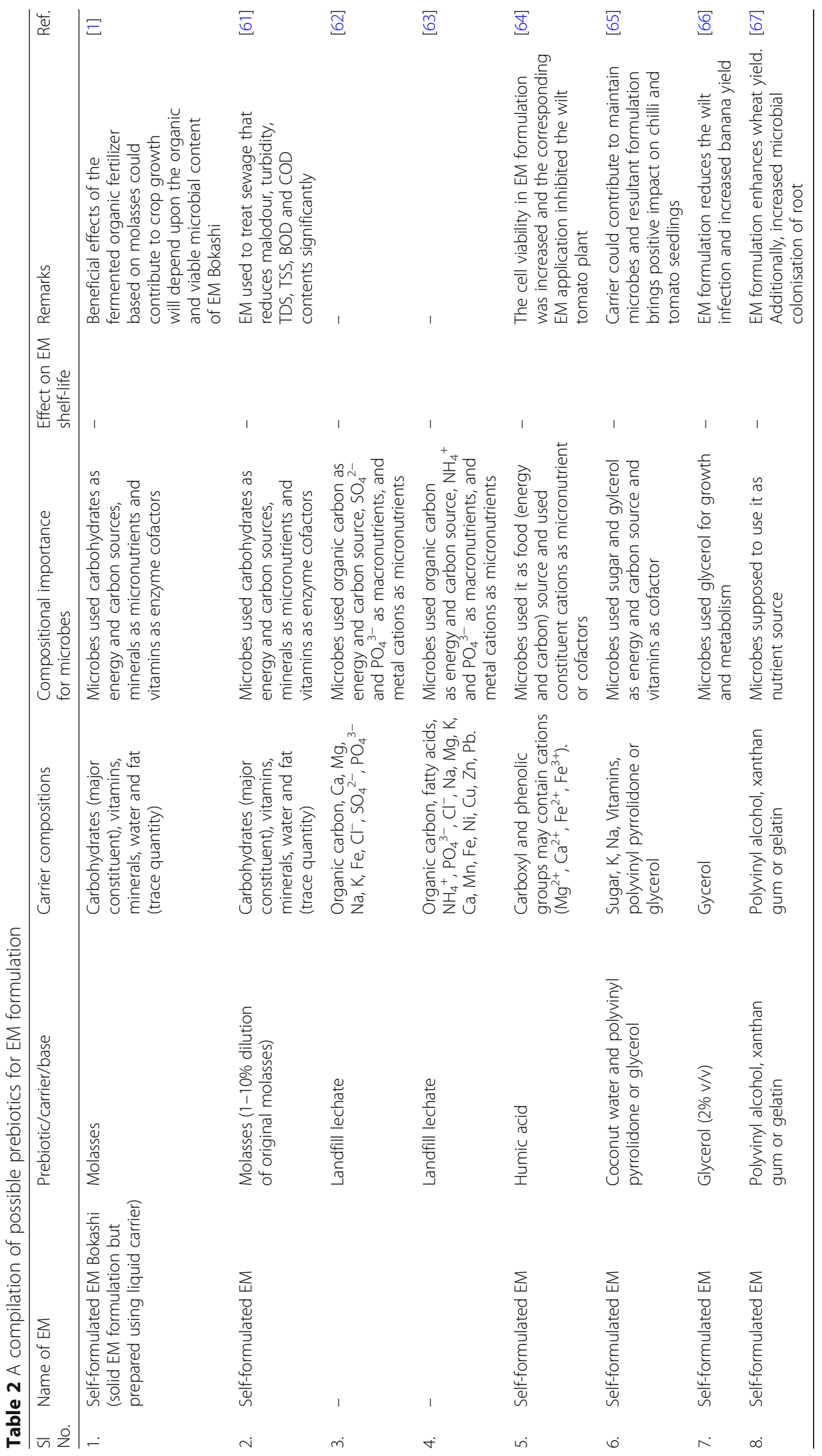


Several soil applications of EM formulations for enhanced growth have been reported. Soil application of EM maintains the photosynthetic efficiency of bean plant 2 weeks longer [26]. Application of compost-based effective microbes (Candida tropicalis, Phanerochaete chrysosporium, Streptomyces globisporous, Lactobacillus sp.) along with chemical fertilizer dosage enhances the carotenoid pigment of calendula and marigold by 46 and $12 \%$, respectively [27]. The specific microbes and their modes of action in plant growth are provided in Table 3 with the impact of rhizosphere-associated EM on plant growth in Table 4. The potential microbial candidates for EM formulation are compiled in Table 5.

\section{Climatic (abiotic) factors and the efficacy of EM formulation}

Although EMs are meant to particularly promote plant growth in harsh (drought, salinity, $\mathrm{CO}_{2}$, high/low temperatures) climatic conditions [38], climatic factors could also affect the growth and survival of EMs thereby affecting plant growth and productivity [81].

There was an improved interaction between legume and rhizobia at elevated ambient $\mathrm{CO}_{2}$ concentration [82]. Atmospheric $\mathrm{CO}_{2}$ fortification facilitates the activity of Rhizobium leguminosarum over other strains [83]. The nitrogen content of plant tissues in common bean decreases at elevated atmospheric $\mathrm{CO}_{2}$ condition [84]. Elevated $\mathrm{CO}_{2}$ stimulates microbial growth in rhizosphere wherein the plant and rhizobia compete for nitrogen which leads to a low N-nutritional status in plant. The population of HCN-producing Pseudomonas sp. (inhibiting root parasitic fungi) is reduced at an elevated $\mathrm{CO}_{2}$ conditions, and the fractions of siderophore-producing and nitrate-dissimilating strains decrease. A study confirmed the dominance of Pseudomonas sp. in rye, and Rhizobium sp. in white clover at elevated $\mathrm{CO}_{2}$ concentration [85]. Pseudomonas mendocina enhances lettuce growth at elevated $\mathrm{CO}_{2}$ condition [86]. At elevated $\mathrm{CO}_{2}$ condition, the plant biomass, foliar $\mathrm{K}$ concentration and water content increase.

Temperature variation could affect microbial activity for plant growth. Decreased temperature may enhance the activity of certain PGPM, while it may be the reverse in some other cases. The root and shoot significantly increase with the activity of Mycobacterium sp., Pseudomonas fluorescens and Pantoea agglomerans at $16^{\circ} \mathrm{C}$ in winter wheat crop in loamy-sandy soil as compared to at $26^{\circ} \mathrm{C}$ [87]. The rhizobia isolated from nodules of woody legume Prosopis glandulosa shows improved growth at $36^{\circ} \mathrm{C}$ than $26^{\circ} \mathrm{C}$ [88]. Bacteria colonising at various sites may respond differently to varying temperature, e.g., an endophyte Burkholderia phytofirmans reduces colonisation in tomato rhizosphere when the temperature increases from 10 to $30^{\circ} \mathrm{C}$ while the endophytic colonisation remains unaffected [89].

Various reports on the effect of drought on the efficacy of effective microbes are available. Azospirillum strains improve the plant-water interaction. Azospirillum application increases wheat, maize and sorghum yields in water-limiting conditions. Pseudomonas putida or Bacillus megaterium and AM fungi (Glomus coronatum, Glomus constrictumor and Glomus claroideum) association induce development and drought forbearance in plants [90].

Table 3 EMs and their specific roles in plant growth promotion

\begin{tabular}{|c|c|c|c|c|}
\hline Microbial category & Isolates & Association & Plant growth promotion & Ref. \\
\hline Bacteria & Rhizobium sp., Bradyrhizobium sp. & Symbiosis (legume-rhizobium) & 1. $\mathrm{N}_{2}$-fixation & {$[11,13,15,76]$} \\
\hline Bacteria & Azospirillum sp., Azotobacter sp. & Asymbiotic (non-legume) & 1. $\mathrm{N}_{2}$-fixation & {$[14,16,17,76]$} \\
\hline Bacteria & $\begin{array}{l}\text { Pseudomonas fluorescens, } \\
\text { Pseudomonas putida, } \\
\text { Pseudomonas aeruginosa, } \\
\text { Bacillus sp. (Bacillus subtilis) }\end{array}$ & Rhizospheric soil & 1. Biocontrol agent & {$[15,77]$} \\
\hline Fungi & Trichoderma viride & & & \\
\hline Bacteria & $\begin{array}{l}\text { Bacillus sp.(B. subtilis, } B \text {. } \\
\text { megaterium, B. mucilaginosus) } \\
\text { Pseudomonas sp., P. fluorescens }\end{array}$ & Rhizospheric soil & $\begin{array}{l}\text { 1. Phosphate solubilisation } \\
\text { 2. } \mathrm{N}_{2} \text {-fixation }\end{array}$ & {$[15,18,70,77]$} \\
\hline Fungi & Aspergillus sp., Penicillium sp. & & & \\
\hline Yeast & Candida tropicalis & & 1. Phosphate solubilisation & {$[77]$} \\
\hline Fungi & Arbuscular mycorrhizal fungi (AMF) & Symbiotic & $\begin{array}{l}\text { 1. Provided tolerance to host plants } \\
\text { against various stressful situations } \\
\text { (heat, salinity, drought, metals and } \\
\text { extreme temperatures) }\end{array}$ & {$[78]$} \\
\hline Actinomycetes & Streptomyces sp. & Rhizospheric soil & $\begin{array}{l}\text { 1. Production of antibiotics, siderophores, } \\
\text { antimicrobial enzymes, plant growth } \\
\text { promoting substances } \\
\text { 2. Phosphate solubilisation }\end{array}$ & {$[79,80]$} \\
\hline
\end{tabular}


Table 4 Rhizosphere associated EMs and their impacts on plant growth

\begin{tabular}{|c|c|c|c|c|}
\hline Microbial category & Microbial consortium & Association & Plant growth promotion & Ref. \\
\hline Bacteria & Rhizobium sp., Bradyrhizobium sp. & Symbiotic (legume-rhizobium) & 1. $\mathrm{N}_{2}$-fixation & [14] \\
\hline Bacteria & Azotobacter sp., Azospirillum sp. & Asymbiotic (non-legume) & 1. $\mathrm{N}_{2}$-fixation & {$[15,17,18$} \\
\hline Bacteria & Pseudomonas putida, P. fluorescens & Rhizosphereic soil & $\begin{array}{l}\text { 1. Biocontrol agents, } \\
\text { 2. Biological } \mathrm{N}_{2} \text {-fixation } \\
\text { 3. Nutrients solubilisation }\end{array}$ & [16] \\
\hline Bacteria & Bacillus megaterium, B. mucilaginosus & Rhizospheric soil & $\begin{array}{l}\text { 1. Phosphate solubilisation } \\
\text { 2. Potassium solubilisation }\end{array}$ & [19] \\
\hline Bacteria and actinomycetes & $\begin{array}{l}\text { Bacillus sp., Pseudomonas } \\
\text { aeruginosa, Streptomyces sp. }\end{array}$ & Rhizospheric soil & $\begin{array}{l}\text { 1. Prevention of sunflower } \\
\text { necrosis disease }\end{array}$ & [31] \\
\hline $\begin{array}{l}\text { Lactic acid bacteria, yeast } \\
\text { and actinomycetes }\end{array}$ & $\begin{array}{l}\text { Lactobacillus plantarum, Candida } \\
\text { utilis, Streptomyces albus }\end{array}$ & Rhizospheric soil & 1. Decomposition of organic matter & [22] \\
\hline $\begin{array}{l}\text { Lactic acid bacteria, } \\
\text { photosynthetic bacteria, } \\
\text { yeast, actinomycetes and } \\
\text { fermentative fungi }\end{array}$ & $\begin{array}{l}\text { Lactobacillus plantarum, L. casei, } \\
\text { Streptoccus lactis, Rhodopseudomonas } \\
\text { palustris, Rhodobacter sphaeroides, } \\
\text { Saccharomyces cerevisiae, Candida } \\
\text { utilis, Streptomyces albus, S. griseus, } \\
\text { Aspergillus oryzae, Mucor hiemalis }\end{array}$ & Rhizospheric soil & $\begin{array}{l}\text { 1. Enhancement of the growth } \\
\text { pattern and nutrient uptake }\end{array}$ & [20] \\
\hline
\end{tabular}

Recombinant DNA technology application has been a successful approach to improve microbial property which in turn stimulates the plant to withstand drought [91]. Trehalose-producing microbes pose the ability to support and promote plant growth under drought stress. There are numerous microbial types that stimulate and promote plant growth under drought stress and these include Burkholderia phytofirmans, Paenibacillus polymyxa, and Actinobacteria [81]. PGPB may stimulate cell division of root and root hairs that eventually help plant to take-up water from deeper soil layer [92]. PGPB may support plant growth under drought situation by regulating abscisic acid and ethylene production [93].

\section{Effect of EMs on crops}

There are several reports of beneficial effects of EMs on crops. This review discusses the effect of EM formulations particularly on cereals, pulses, oilseeds, and vegetable crops. The rationale behind these selected groups of crops is based on the economic value and their popularity among the Indian farming community. EM formulations and their effect on crops are shown in Table 6.

\section{Cereals}

Rice (Oryza sativa) is the staple cereal crop in India, and is a principal food for the half of the world's population. Approximately 480 MMT milled rice are produced annually to feed the increasing global population. Flooding is the conventional approach for rice cropping which means that there is a need for a huge quantity of water. Yet, around $50 \%$ of the rice cultivated area worldwide suffers from drought. Water deficit impacts the crops negatively and might result in a significant yield reduction, especially during critical stages of crop growth $[104,105]$.

Drought stress affects the crop yield significantly as the nutrient uptake by plants decreases. Thus, attempts to engineer draught-tolerant crops requiring less water while maintaining or enhancing the production are

Table 5 Various EMs for formulation

\begin{tabular}{|c|c|c|c|}
\hline Microorganisms & Species & Function & Ref. \\
\hline Photosynthetic bacteria & $\begin{array}{l}\text { Rhodopsedomonas palustris } \\
\text { Rhodobacter sphaeroides }\end{array}$ & $\begin{array}{l}\text { 1. Produces amino acids, nucleic acids, bioactive } \\
\text { substances and sugars } \\
\text { 2. Conducts photosynthesis }\end{array}$ & {$[20,24,25,30,32]$} \\
\hline Lactic acid bacteria & $\begin{array}{l}\text { Lactobacillus plantarum } \\
\text { Lactobacillus casei } \\
\text { Streptococcus lactis }\end{array}$ & $\begin{array}{l}\text { 1. Supresses and reduce pathogenic microbes } \\
\text { 2. Expedites decomposition of organic matters }\end{array}$ & {$[20,22,24,25,30,32]$} \\
\hline Actinomycetes & $\begin{array}{l}\text { Streptomyces albus } \\
\text { Streptomyces griseus }\end{array}$ & $\begin{array}{l}\text { 1. Produces antimicrobial substances to inhibit pathogens } \\
\text { 2. Enhances the decomposition of phospholipid compounds }\end{array}$ & {$[11,22,24,25,30,31]$} \\
\hline Fermentative fungi & $\begin{array}{l}\text { Aspergillus orizae } \\
\text { Mucor heimalis }\end{array}$ & $\begin{array}{l}\text { 1. Decomposes organic matter } \\
\text { 2. Synthesises amino acids and glucose from carbohydrates } \\
\text { 3. Control odours }\end{array}$ & {$[20,29]$} \\
\hline Yeast & $\begin{array}{l}\text { Saccharmyces cerevisiae } \\
\text { Candida utilis }\end{array}$ & 1. Degrades dead plant tissue and stimulate root growth & {$[20,22,24,25,30,32]$} \\
\hline
\end{tabular}


Table 6 EM formulations and their effect on crops

\begin{tabular}{|c|c|c|c|c|}
\hline Crop type & Crop & Microbes in EM formulations & Effect on crops & Ref. \\
\hline \multirow[t]{4}{*}{ Cereal } & \multirow[t]{4}{*}{ Rice } & Arbuscular mycorrhiza fungi, Glomus intraradices & $\begin{array}{l}\text { 1. Improved growth of rice crops under drought } \\
\text { pressure }\end{array}$ & [94] \\
\hline & & Bacillus subtilis, Pseudomonas fluorescens & 1. Biocontrol agents with anatagonistic nature & [41] \\
\hline & & Azospirillum brasilense, Phyllobacterium brassicacearum & $\begin{array}{l}\text { 1. Growth of plants under drought situation and } \\
\text { nutrient limitation }\end{array}$ & [95] \\
\hline & & $\begin{array}{l}\text { Pseudomonas putida (or Bacillus megaterium) and AM fungi } \\
\text { (Glomus coronatum, Glomus constrictum, Glomus claroideum) }\end{array}$ & 1. Plant development and drought tolerance & [90] \\
\hline \multirow[t]{3}{*}{ Pulses } & Rajmah & $\begin{array}{l}\text { Pseudomonas lurida-NPRp15, P. putida-PGRs4, Rhizobium } \\
\text { leguminosarum-FB1 }\end{array}$ & 1. Effective for plant growth through $\mathrm{N}_{2}$-fixation & [96] \\
\hline & Bean & $\begin{array}{l}\text { Rhizobium sp., Bacillus megaterium (M-3), Bacillus } \\
\text { subtilis (OSU-142) }\end{array}$ & $\begin{array}{l}\text { 1. } \mathrm{N}_{2} \text {-fixation } \\
\text { 2. Phosphate solublisation }\end{array}$ & [97] \\
\hline & Soybean & Bradyrhizobium japonium & 1. Symbiotic $\mathrm{N}_{2}$-fixation & [98] \\
\hline \multirow[t]{7}{*}{ Oilseed } & \multirow[t]{4}{*}{ Sunflower } & Rhizobium sp., Trichoderma hamatum & $\begin{array}{l}\text { 1. Increase inchlrophyll, root and shoot length, mineral } \\
\text { ( } \mathrm{N} \text { and } \mathrm{P}) \text {, total carbohydrate and protein contents of } \\
\text { crop }\end{array}$ & [98] \\
\hline & & Pseudomonas putida & 1. Drought tolerance & [31] \\
\hline & & Trichoderma harzianum & 1. Plasmopora halstedii targeted & \\
\hline & & Bacillus sp., Pseudomonas aeruginosa, Streptomyces sp. & 1. Inhibited sunflower necrosis disease & [99] \\
\hline & \multirow[t]{3}{*}{ Grounnut } & Azospirillum brasilense & 1. Enhanced tap root growth & [100] \\
\hline & & Pseudomonas fluorescens & 1. Stimulated lateral root growth & \\
\hline & & Actinomycetes & $\begin{array}{l}\text { 1. Hydrogen cyanide, lipase, siderophores, and indole } \\
\text { acitic acid production } \\
\text { 2. Inhibited soil born pathogens such as Sclerotium rolfsii }\end{array}$ & [45] \\
\hline \multirow[t]{3}{*}{ Vegetables } & \multirow[t]{3}{*}{ Okra } & Enterobacter sp. UPMR18 & 1. Helped in salt tolerance under salinity stress & [101] \\
\hline & & Trichoderma harzianum & 1. Supressed fungal infections & [102] \\
\hline & & Pseudomonas aeruginosa, Trichoderma viride & $\begin{array}{l}\text { 1. Biocontrol against Fusarium oxysporum, F. solani, } \\
\text { Macrophomina phaseolina, Rhizoctonia solani and } \\
\text { Meloidogyne javanica }\end{array}$ & [103] \\
\hline
\end{tabular}

being made. Genetically variant drought tolerant variety could have enhanced proline and abscisic acid production, stabilized superoxide dismutase activity for photosynthesis and improved root system [106]. Using a consortium of advantageous microbes is a prospect towards enhancing drought-resistant plant. Soil microbes like AMF attached to plant roots interact with specific microbial communities to develop an array of activities to enhance crop growth and yield under drought stress conditions [107].

Rice readily forms mycorrhizal associations in upland conditions. However, this is uncommon in flooded conditions as the anoxic condition develops at plant-soil interface. To encourage arbuscular mycorrhiza (AM) symbiosis, aerobic non-flooded farming conditions to boost establishment of AM fungi in the rice roots may be resorted [108]. AMF stimulate the metabolic response in plant under drought stress [109]. AMF Glomus intraradices enhances rice growth under drought condition where the shoot weight increases by $50 \%$ with AM symbiosis compared to the non-AM plants [94]. The photosynthesis increases by $40 \%$ along with the accumulation of antioxidant molecule glutathione. AM symbiosis reduces hydrogen peroxide and decreases oxidative damage to the lipids [94, 110]. Positive association in Pseudomonas putida or Bacillus megaterium and AM fungi (Glomus coronatum, Glomus constrictum or Glomus claroideum) in drought situations positively affect crop development and drought forbearance [90]. PGPR like Azospirillum brasilense, Phyllobacterium brassicacearum and AM fungi increases crop survival in drought and nutrient limitation like situations. Biomass growth and grain yield increase in rice by applying these microbial formulations $[95,111]$.

\section{Pulses}

Majority of the global population depend on pulses for the major amount of their protein requirements. Pulses primarily include chickpea, rajmah, black gram, green gram, beans and lentil. Of these, black gram is a major food crop in India [41]. Green gram (Vigna radiata) and black gram (Vigna mungo) grown under tropical and subtropical conditions are important food legume as protein source. As these are almost free from gassiness 
causing factors, green gram and black gram seeds are preferred to feed babies.

India is on the way to develop alternative agricultural practices to obtain higher pulses yield to fulfil the need of its larger population. EM formulation enhances crop growth and yield in both leguminous and nonleguminous pulses. Pseudomonas lurida-NPRp15 and Psedomonas putida-PGRs4 either individually or in combination with Rhizobium leguminosarum-FB1 are effective in growing rajmah [96]. While individual inoculant increases plant dry biomass, nitrogen, phosphorus, potassium, zinc and iron contents, Pseudomonas lurida NPRp15 and Rhizobium leguminosarum FB1 (or Pseudomonas putida PGRs4, Pseudomonas lurida NPRp15 and Rhizobium leguminosarum FB1) combination enhance the root and shoot dry weight, nutrient uptake, nutrient content, nodulation and pod yield in rajmah [96]. The EM of Rhizobium, phosphate-solubilising Bacillus megaterium (M-3) and $\mathrm{N}_{2}$-fixing Bacillus subtilis (OSU-142) has also been encouraging on bean plant. These are effective in nutrient uptake, nodulation, shoot and root dry weight, seed yield and plant growth. These are equally more effective as compared to chemical fertiliser as well [97].

\section{Oilseeds}

Sunflower (Helianthus annuus) is an important oilseed crop and is the second most important source of global vegetable oil. India ranks 4th by area and 8th in production of sunflower. Karnataka, Andhra Pradesh and Maharashtra are the major sunflower growers contributing about $91 \%$ of the total sunflower cultivation area and $82 \%$ of total sunflower production [112]. Wheat bran compost containing Rhizobium sp. and Trichoderma hamatum, either individually or in combination, shows an increase in total chlorophyll, root and shoot lengths, minerals (nitrogen and phosphorus), carbohydrate and protein contents in sunflower [98]. Applying symbiotic nitrogen-fixer Bradyrhizobium japonium (strain TAL102) EM as biofertilizer or in combination with farm (or green) manure in soybean has positive benefit. Coinoculating Bradyrhizobium japonicum and biofertilizer with farmyard manure exhibits the highest biomass of the shoot, number and biomass of pods compared to other treatments [113]. EM formulation of Azospirillum brasilense and Pseudomonas fluorescens individually or mixed has been applied on groundnut plant through seed treatment, soil application, seedling root tip and foliar spray [99]. Azospirillum brasilense enhances tap root growth, whereas Pseudomonas fluorescens is effective in lateral root growth. A consortium mix enhances leaf numbers and shoot growth. Out of all treatments, soil application is the most effective [99].
Drought tolerance of oilseed plant could increase by applying suitable microbial formulation. Sunflower seeds treated with Pseudomonas putida could withstand drought [31]. Besides drought tolerance, EM is effective against plant pathogens in sunflower. Applying Trichoderma hazianum suspension on sunflower crop prevents it from Plasmopora halstedii (downy mildew). Seed treatment of sunflower with mixed consortium of Bacillus sp., Pseudomonas aeruginosa and Streptomyces sp. is fruitful against sunflower necrosis viral disease [31]. EM formulation increases disease resistance in groundnut; actinomycetes could prevent stem rot disease (by Sclerotium rolfsii) [100]. Actinomycetes inhibit Sclerotium rolfsii by producing various antibiotics/chemical agents, viz., hydrogen cyanide, lipase, siderophores and indole acetic acid [100].

\section{Vegetable plant}

Okra (Abelmoschus esculentus) is grown throughout the tropical and warm temperate regions for its fibrous pods eaten as a vegetable. It is attacked by numerous insect pests. Various insect pest's infestation that decrease the pod yield in okra include fruit borers, shoot borers, leaf hoppers, sucking insects, chewing insects, aphids, root feeding insects, and mites. They suck the cell sap of the plant thereby destroying the plant vigor. The crop is tolerant to the most of the insect pests in wet season, while leaf hoppers and aphids may cause damage during dry season [114]. Although chemical control of the pests is generally practiced for higher yield, use of chemicals alone is not advisable due to shorter interval in the periodical harvest. Thus, it becomes relevant to look for effective and eco-friendly alternatives.

Wokozim, kissan supreme tonic (KST) and EM formulation (foliar) applications in okra for pest control show that KST application is the most effective against sucking pest complex and pod borers resulting in the increase in pod yield. It has been shown that although EM application results in low pod yield as compared to KST and Wokozim but it results in higher final yield (8431 $\mathrm{kg} \mathrm{ha}^{-1}$ ) as compared to $8012 \mathrm{~kg} \mathrm{ha}^{-1}$ in control [38]. Siddiqui et al. [101] suggested that Trichodermaenriched compost was more eco-friendly as against inorganic fertilisers, and enhanced crop yield by benefitting okra cultivation. EM formulation of Enterobacter sp. UPMR18 enhances the salt tolerance property of okra; while enhancing salt tolerance it also enhances its germination percentage as well as chlorophyll content [45].

Strains of Pseudomonas aeruginosa alone or with Trichoderma viride (entophytic bacteria) exhibit substantially enhanced disease resistance in okra against Fusarium oxysporum, Fusarium solani, Macrophomina phaseolina, Rhizoctonia solani and Meloidogyne javanica (the root knot nematode). It brings positive impact on plant growth by improving plant height, fresh shoot 
weight and root length [102]. Brucella K12 strain, a $\mathrm{Cr}(\mathrm{VI})$ reducing bacterium, reportedly enhances the growth/yield of okra in Cr-contaminated soils [103].

\section{Conclusions}

EMs enhance plant growth and productivity by fixing atmospheric $\mathrm{N}_{2}$ and supplementing the plants with the fixed nitrogen as ammonia. Additionally, the release of trace elements, secreted antioxidant, exopolysaccharides, bioactive compounds (vitamins, hormones and enzymes) by the EMs stimulate plant growth and productivity. Biocontrol agents secreted by the EMs protect the plants from harmful microbes as also from environmental stress. EMs contain primarily the photosynthetic and lactic acid bacteria, fermentative fungi, yeasts, actinomycetes, among others and could be formulated by adding a solid or a liquid carrier to it. The resulting EM formulation could be applied to the soil by spraying on leaves (foliar application), soaking seeds in it (seed treatment) and through irrigation (fertigation/soil application). The review discusses the impact of various EM formulations on cereals, pulses, oilseed and vegetable plants. Application of EM formulation improves grain productivity, biomass accumulation, photosynthesis efficiency and drought tolerance in cereals. It increases the trace elements, biomass, shoot weight, root weight, modulation, pod production in rajmah, and nodulation, root-shoot weight and seed yield in bean. It increases shoot weight, pod number and biomass in soybean. EM formulation positively affects root-shoot growth, chlorophyll, nitrogen, phosphorus, carbohydrate and protein content, drought tolerance, virus resistance, leaf number and fungal disease resistance in sunflower and groundnut. In vegetable plants like okra, EM formulation improves the shoot-root growth, plant height, chlorophyll content, pod yield, fungal disease resistance, $\mathrm{Cr}$-resistance and insect pest resistance. Thus, for sustainable and more promising green agriculture, microbial formulations have an important and indispensable role to play in modern agriculture for cropping of cereals, pulses, oilseeds and vegetables.

\section{Acknowledgements}

The cooperation, encouragement and infrastructure extended by the affiliated Institute is duly acknowledged and appreciated.

\section{Authors' contributions}

$\mathrm{KN}$ and HS prepared the primary manuscript. PKS and AC helped in providing results, information and preparation of tables and figures. SM conceptualised, revised, corrected and edited the manuscript. All the authors have read and approve the final manuscript. KN and HS contributed equally as first authors.

\section{Funding}

The funding source for this project work was supported by Rajiv Gandhi National Fellowship scheme from the University Grants Commission (UGC), Government of India.

\section{Availability of data and materials}

The datasets presented and analysed in this review are submitted together with the manuscript. Such datasets are available from corresponding author on reasonable request.

\section{Competing interests}

The authors declare no competing and/or conflict of interests.

Received: 16 July 2019 Accepted: 16 April 2020

Published online: 13 May 2020

\section{References}

1. Yamada K, Xu HL. Properties and applications of an organic fertilizer inoculated with effective microorganisms. J Crop Prod. 2001;3:255-68.

2. Ghosh PK, Ramesh P, Bandyopadhyay KK, Tripathi AK, Hati KM, Misra A. Comparative effectiveness of cattle manure, poultry manure, phosphocompost and fertilizer-NPK on three cropping systems in vertisols of semi-arid tropics. I. Crop yields and system performance. Bioresour Technol. 2004;95:77-83.

3. Kumar BL, Gopal DVRS. Effective role of indigenous microorganisms for sustainable environment. 3. Biotech. 2015;5:867-76

4. Liu YB, Pan XB, Li JS. A 1961-2010 record of fertilizer use, pesticide application and cereal yields: a review. Agron Sustain Dev. 2015;35:83-93.

5. Calderon K, Spor A, Breuil MC, Bru D, Bizouard F, Violle C, et al. Effectiveness of ecological rescue for altered soil microbial communities and functions. ISME J. 2017:11:272-83.

6. Kuhad RC. Microbes and their role in sustainable development. Indian J Microbiol. 2012:52:309-13.

7. terHorst CP, Lennon JT, Lau JA. The relative importance of rapid evolution for plant-microbe interactions depends on ecological context. P Roy Soc BBiol Sci. 2014:281:20140028.

8. Alori ET, Babalola OO. Microbial inoculants for improving crop quality and human health in Africa. Front Microbiol. 2018:9:2213.

9. Singh JS, Pandey VC, Singh DP. Efficient soil microorganisms: a new dimension for sustainable agriculture and environmental development. Agric Ecosyst Environ. 2011;140:339-53.

10. Towett G. What are effective microorganisms? The Premaculture Research Institute: The Channon; 2016

11. Yosefi K, Galavi M, Ramrodi M, Mousavi SR. Effect of bio-phosphate and chemical phosphorus fertilizer accompanied with micronutrient foliar application on growth, yield and yield components of maize (single cross 704). Aust J Crop Sci. 2011;5:175-80.

12. Shen ZZ, Zhong ST, Wang YG, Wang BB, Mei XL, et al. Induced soil microbial suppression of banana fusarium wilt disease using compost and biofertilizers to improve yield and quality. Eur J Soil Biol. 2013;57:1-8.

13. Naik K, Mishra S, Srichandan H, Singh PK, Sarangi PK. Plant growth promoting microbes: potential link to sustainable agriculture and environment. Biocatal Agric Biotech. 2019;21:101326.

14. Zahran $\mathrm{HH}$. Rhizobium-legume symbiosis and nitrogen fixation under severe conditions and in an arid climate. Microbiol Mol Biol R. 1999:63:96889.

15. Lin SY, Hameed A, Liu YC, Hsu YH, Lai WA, Shen FT, et al. Azospirillum soli sp nov., a nitrogen-fixing species isolated from agricultural soil. Int J Syst Evol Microbiol. 2015;65:4601-7.

16. de Souza R, Ambrosini A, Passaglia LMP. Plant growth-promoting bacteria as inoculants in agricultural soils. Genet Mol Biol. 2015;38:401-19.

17. Wani SA, Chand S, Ali T. Potential use of Azotobacter chroococcum in crop production: an overview. Cur Agr Res J. 2013;1:35-8.

18. Rueda D, Valencia G, Soria N, Rueda BB, Manjunatha B, Kundapur RR, et al. Effect of Azospirillum spp. and Azotobacter spp. on the growth and yield of strawberry (Fragaria vesca) in hydroponic system under different nitrogen levels. J Appl Pharm Sci. 2016;6:048-54

19. Han HS, Lee KD. Phosphate and potassium solubilizing bacteria effect on mineral uptake, soil availability and growth of eggplant. Res J Agric Biol Sci. 2005;1:176-80.

20. Kato S, Xu HL, Fujita M, Yamada K, Karase K, Umemura H. Effect of organic fertilizations and EM applications on growth pattern, nutrient uptake and grain yield of sweet corn. South Africa. In: 6th International Conference on Kyusei Nature Farming Pretoria. Pretoria; 1999.

21. Sreenivasan E. Evaluation of effective microorganisms technology in industrial wood waste management. Int J Adv Eng Tech. 2013;IV:21-2. 
22. Raja NSK, Bharani RSA. Effect of compost derived from decomposed fruit wastes by effective microorganism (EM) technology on plant growth parameters of Vigna mungo. J Bioremed Biodegr. 2012;3:1000167.

23. Javaid A, Shah MBM. Growth and yield response of wheat to EM (effective microorganisms) and parthenium green manure. Afr J Biotechnol. 2010;9: 3373-81.

24. Javaid A. Foliar application of effective microorganisms on pea as an alternative fertilizer. Agron Sustain Dev. 2006;26:257-62

25. Javaid A, Bajwa R, Anjum T. Effect of heat-sterilization and EM (effective microorganisms) application on wheat (Triticum aestivum L.) grown in organic-amended sandy loam soil. Cereal Res Commun. 2008;36:489-99.

26. Iriti M, Scarafoni A, Pierce S, Castorina G, Vitalini S. Soil application of effective microorganisms (EM) Maintains leaf photosynthetic efficiency, increases seed yield and quality traits of bean (Phaseolus vulgaris $\mathrm{L}$.) plants grown on different substrates. Int J Mol Sci. 2019;20:2327.

27. Sharma A, Saha TN, Arora A, Shah R, Nain L. Efficient microorganism compost benefits plant growth and improves soil health in Calendula and Marigold. Hortic Plant J. 2017;3:67-72.

28. Schoebitz M, Lopez MD, Serri H, Martinez O, Zagal E. Combined application of microbial consortium and humic substances to improve the growth performance of blueberry seedlings. J Soil Sci Plant Nutr. 2016;16:1010-23.

29. Maiyappan S, Amalraj ELD, Santhosh A, Peter AJ. Isolation, evaluation and formulation of selected microbial consortia for sustainable agriculture. J Biofert Biopestic. 2010;2:1000109.

30. Hu C, Xia XG, Chen YF, Han XM. Soil carbon and nitrogen sequestration and crop growth as influenced by long-term application of effective microorganism compost. Chil J Agr Res. 2018;78:13-22.

31. O'Callaghan M. Microbial inoculation of seed for improved crop performance: issues and opportunities. Appl Microbiol Biotechnol. 2016;100: 5729-46.

32. Javaid A. Beneficial microorganisms for sustainable agriculture. In: Lichtfouse E, editor. Genetic engineering, biofertilisation, soil quality and organic farming. Sustainable agriculture reviews, vol. 4. Dordrecht: Springer; 2010. p. $347-69$

33. Lal R, Delgado JA, Groffman PM, Millar N, Dell C, Rotz A. Management to mitigate and adapt to climate change. J Soil Water Conserv. 2011;66:276-85.

34. Li WJ, Ni YZ. Use of effective microorganisms to suppress malodors of poultry manure. J Crop Prod. 2001;3:215-21.

35. Balogun RB, Ogbu JU, Umeokechukwu EC, Kalejaiye-Matti RB. Effective micro-organisms (EM) as sustainable components in organic farming: principles, applications and validity. In: Nandwani D, editor. Organic farming for sustainable agriculture. Sustainable development and biodiversity, vol. 9. Cham: Springer; 2016. p. 259-91.

36. Sangakkara UR. The technology of effective microorganisms - case studies of application. Cirencester: Royal Agricultural College; 2002.

37. Mehta CM, Palni U, Franke-Whittle IH, Sharma AK. Compost: its role, mechanism and impact on reducing soil-borne plant diseases. Waste Manag. 2014;34:607-22.

38. Ali SS, Pusio WA, Rizwana H, Ali SS, Ghouri S, Ahmad SS. Effect of some micronutrients on damage compensation and yield parameters in okra. Aust J Basic Appl Sci. 2012;8:618-24.

39. Backer R, Rokem JS, llangumaran G, Lamont J, Praslickova D, Ricci E, et al. Plant growth-promoting rhizobacteria: context, mechanisms of action, and roadmap to commercialization of biostimulants for sustainable agriculture. Front Plant Sci. 2018;9:1473.

40. Hayat R, Ali S, Amara U, Khalid R, Ahmed I. Soil beneficial bacteria and their role in plant growth promotion: a review. Ann Microbiol. 2010;60:579-98.

41. Sivasakthi S, Usharani G, Saranraj P. Biocontrol potentiality of plant growth promoting bacteria (PGPR) - Pseudomonas fluorescens and Bacillus subtilis: a review. Afr J Agric Res. 2014;9:1265-77.

42. Kruasuwan $W$, Thamchaipenet A. Diversity of culturable plant growthpromoting bacterial endophytes associated with sugarcane roots and their effect of growth by co-inoculation of diazotrophs and actinomycetes. J Plant Growth Regul. 2016;35:1074-87.

43. Verma VC, Gond SK, Kumar A, Mishra A, Kharwar RN, Gange AC. Endophytic actinomycetes from Azadirachta indica a. Juss.: isolation, diversity, and antimicrobial activity. Microb Ecol. 2009;57:749-56.

44. Qin S, Feng WW, Wang TT, Ding P, Xing K, Jiang JH. Plant growthpromoting effect and genomic analysis of the beneficial endophyte Streptomyces sp KLBMP 5084 isolated from halophyte Limonium sinense. Plant Soil. 2017;416:117-32.
45. Habib SH, Kausar H, Saud HM. Plant growth-promoting rhizobacteria enhance salinity stress tolerance in okra through ROS-scavenging enzymes. Biomed Res Int. 2016;2016:6284547 https://doi.org/10.1155/2016/6284547.

46. Braga RM, Dourado MN, Araujo WL. Microbial interactions: ecology in a molecular perspective. Braz J Microbiol. 2016;47:86-98.

47. Mougi A. The roles of amensalistic and commensalistic interactions in large ecological network stability. Sci Rep. 2016;6:29929.

48. Tshikantwa TS, Ullah MW, He F, Yang G. Current trends and potential applications of microbial interactions for human welfare. Front Microbiol. 2018:9:1156

49. Bohlen PJ, Groffman PM, Driscoll CT, Fahey TJ, Siccama TG. Plant-soilmicrobial interactions in a northern hardwood forest. Ecology. 2001;82:96578.

50. van Bruggen AHC, Goss EM, Havelaar A, van Diepeningen AD, Finckh MR, Morris JG. One health - cycling of diverse microbial communities as a connecting force for soil, plant, animal, human and ecosystem health. Sci Total Environ. 2019;664:927-37.

51. Hirsch AM. Plant-microbe symbioses: a continuum from commensalism to parasitism. Symbiosis. 2004:37:345-63.

52. Selim SM, Zayed MS. Microbial interactions and plant growth. In: Singh D, Singh H, Prabha R, editors. Plant-microbe interactions in agro-ecological prospectives. Singapore: Springer; 2017. p. 1-15.

53. Zakaria Z, Gairola S, Shariff NM. Effective microorganisms (EM) technology for water quality restoration and potential for sustainable water resources and management. In: International Congress on Environmental Modelling and Software. Ottawa; 2010.

54. Higa T, Parr JF. Beneficial and effective microorganisms for a sustainable agriculture and environment. Atami: International Nature Farming Research Center; 1994.

55. Savadogo A, Ouattara CAT, Bassole IHN, Traore AS. Antimicrobial activities of lactic acid bacteria strains isolated from Burkina Faso fermented milk. Pak J Nutr. 2004;3:174-9.

56. Golec AFC, Perez PG, Lokare C. Effective microorganisms: myth or reality? Rev Peru Biol. 2007;14:315-9.

57. Sun PF, Fang WT, Shin LY, Wei JY, Fu SF, Chou JY. Indole-3-acetic acidproducing yeasts in the phyllosphere of the carnivorous plant Drosera indica L. PLoS One. 2014;9:e114196.

58. Olle $M$, Williams $\mid H$. Effective microorganisms and their influence on vegetable production - a review. J Hortic Sci Biotechnol. 2013;88:380-6.

59. Malusa E, Sas-Paszt L, Ciesielska J. Technologies for beneficial microorganisms inocula used as biofertilizers. Sci World J. 2012;2012:491206.

60. Bargaz A, Lyamlouli K, Chtouki M, Zeroual Y, Dhiba D. Soil microbial resources for improving fertilizers efficiency in an integrated plant nutrient management system. Front Microbiol. 2018;9:1606.

61. Monica S, Karthik L, Mythili S, Sathiavelu A. Formulation of effective microbial consortia and its application for sewage treatment. J Microbial Biochem Technol. 2011;3:051-5.

62. Stefanakis A, Akaratos CS, Tsihrintzis VA. Treatment of special wastewaters in VFCWs. In: Stefanakis A, Akaratos CS, Tsihrintzis VA, editors. Vertical flow constructed wetlands. Amsterdam: Elsevier; 2014. p. 145-64.

63. Luo HW, Zeng YF, Cheng Y, He DQ, Pan XL. Recent advances in municipal landfill leachate: a review focusing on its characteristics, treatment, and toxicity assessment. Sci Total Environ. 2020;703:135468.

64. Pushpa A, Subhash PC, Reddy MAH. Development of liquid formulation for the dual purpose of crop protection and production. J Environ Res Dev. 2014;8:378-83.

65. Anith KN, Vyshakhi AS, Viswanathan A, Varkey S, Aswini S. Population dynamics and efficiency of coconut water based liquid formulation of Pseudomonas fluorescens AMB-8. J Trop Agric. 2017;54:184-9.

66. Selvaraj S, Ganeshamoorthi P, Anand T, Raguchander T, Seenivasan N, Samiyappan R. Evaluation of a liquid formulation of Pseudomonas fluorescens against Fusarium oxysporum f. sp cubense and Helicotylenchus multicinctus in banana plantation. BioControl. 2014:59:345-55.

67. Bernabeu PR, Garcia SS, Lopez AC, Vio SA, Carrasco N, Boiardi IL, et al. Assessment of bacterial inoculant formulated with Paraburkholderia tropica to enhance wheat productivity. World J Microbiol Biotechnol. 2018;34:81.

68. Trivedi P, Pandey A, Palni LMS. Carrier-based preparations of plant growthpromoting bacterial inoculants suitable for use in cooler regions. World J Microbiol Biotechnol. 2005;21:941-5.

69. Mwegoha W. Anaerobic composting of pyrethrum waste with and without effective microorganisms. Afr J Environ Sci Technol. 2012;6:293-9 Mazid M, 
Khan TA. Future of bio-fertilizers in Indian agriculture: an overview. Int J Agr Food Res. 2014;3:10-23..

70. Yeoh CY, Chin NL, Tan CS, Ooi HS. Acceleration effects of microbial inoculum on palm oil mill organic waste composting. Compost Sci Util. 2011;19:135-42.

71. Pahari A, Pradhan A, Maity S, Mishra BB. Carrier based formulation of plant growth promoting Bacillus species and their effect on different crop plants. Int J Curr Microbiol App Sci. 2017;6:379-85.

72. Tripathi S, Das A, Chandra A, Varma A. Development of carrier-based formulation of root endophyte Piriformospora indica and its evaluation on Phaseolus vulgaris L. World J Microbiol Biotechnol. 2015;31:337-44.

73. Sahu PK, Brahmaprakash GP. Formulations of biofertilizers - approaches and advances. In: Singh D, Singh H, Prabha R, editors. Microbial inoculants in sustainable agricultural productivity. New Delhi: Springer; 2016. p. 179-98.

74. Srinivasan K, Mathivanan N. Biological control of sunflower necrosis virus disease with powder and liquid formulations of plant growth promoting microbial consortia under field conditions. Biol Control. 2009:51:395-402.

75. Panda H. Integrated organic farming handbook. New Delhi: Asia Pacific Business Press Inc; 2013.

76. Sharma SB, Sayyed RZ, Trivedi MH, Gobi TA. Phosphate solubilizing microbes: sustainable approach for managing phosphorus deficiency in agricultural soils. SpringerPlus. 2013;2:587.

77. Begum N, Qin C, Ahanger MA, Raza S, Khan Ml, Ashraf M, et al. Role of arbuscular mycorrhizal fungi in plant growth regulation: implications in abiotic stress tolerance. Front Plant Sci. 2019;10:1068.

78. Doumbou CL, Salove MKH, Crawford DL, Beaulieu C. Actinomycetes, promising tools to control plant diseases and to promote plant growth. Phytoprotection. 2001;82:85-102.

79. Singh SP, Gupta R, Gaur R, Srivastava AK. Streptomyces spp. alleviate Rhizoctonia solani-mediated oxidative stress in Solanum lycopersicon. Ann Appl Biol. 2016;168:232-42.

80. Compant $\mathrm{S}$, van der Heijden MG, Sessitsch A. Climate change effects on beneficial plant-microorganism interactions. FEMS Microbiol Ecol. 2010;73: 197-214.

81. Hebeisen T, Luscher A, Nosberger J. Effects of elevated atmospheric $\mathrm{CO}_{2}$ and nitrogen fertilisation on yield of Trifolium repens and Lolium perenne. Acta Oecol. 1997;18:277-84.

82. Montealegre $\mathrm{CM}$, van Kessel $\mathrm{C}$, Blumenthal JM, Hur HG, Hartwig UA Sadowsky MJ. Elevated atmospheric $\mathrm{CO}_{2}$ alters microbial population structure in a pasture ecosystem. Glob Chang Biol. 2000;6:475-82

83. Haase S, Philippot L, Neumann G, Marhan S, Kandeler E. Local response of bacterial densities and enzyme activities to elevated atmospheric $\mathrm{CO}_{2}$ and different $\mathrm{N}$ supply in the rhizosphere of Phaseolus vulgaris L. Soil Biol Biochem. 2008:40:1225-34.

84. Marilley L, Hartwig UA, Aragno M. Influence of an elevated atmospheric $\mathrm{CO}_{2}$ content on soil and rhizosphere bacterial communities beneath Lolium perenne and Trifolium repens under field conditions. Microb Ecol. 1999;38: 39-49.

85. Kohler J, Caravaca F, del Mar AM, Roldan A. Elevated $\mathrm{CO}_{2}$ increases the effect of an arbuscular mycorrhizal fungus and a plant-growth-promoting rhizobacterium on structural stability of a semiarid agricultural soil under drought conditions. Soil Biol Biochem. 2009:41:1710-6.

86. Egamberdiyeva D, Hoflich G. Influence of growth-promoting bacteria on the growth of wheat in different soils and temperatures. Soil Biol Biochem. 2003;35:973-8.

87. Waldon $H B$, Jenkins MB, Virginia RA, Harding EE. Characteristics of woodland rhizobial populations from surface- and deep-soil environments of the Sonoran Desert. Appl Environ Microbiol. 1989;55:3058-64.

88. Pillay VK, Nowak J. Inoculum density, temperature, and genotype effects on in vitro growth promotion and epiphytic and endophytic colonization of tomato (Lycopersicon esculentum L.) seedlings inoculated with a pseudomonad bacterium. Can J Microbiol. 1997;43:354-61.

89. Marulanda A, Barea JM, Azcon R. Stimulation of plant growth and drought tolerance by native microorganisms (AM fungi and bacteria) from dry environments: mechanisms related to bacterial effectiveness. J Plant Growth Regul. 2009;28:115-24.

90. Rodriguez-Salazar J, Suarez R, Caballero-Mellado J, Iturriaga G. Trehalose accumulation in Azospirillum brasilense improves drought tolerance and biomass in maize plants. FEMS Microbiol Lett. 2009;296:52-9.

91. Michiels K, Vanderleyden J, Van Gool A. Azospirillum-plant root associations: a review. Biol Fertil Soils. 1989;8:356-68.
92. Aroca R, Ruiz-Lozano JM. Induction of plant tolerance to semi-arid environments by beneficial soil microorganisms - a review. In: Lichtfouse $E_{\text {, }}$ editor. Climate change, intercropping, pest control and beneficial microorganisms. Dordrecht: Springer; 2009. p. 121-35.

93. Ruiz-Sanchez M, Aroca R, Munoz Y, Polon R, Ruiz-Lozano JM. The arbuscular mycorrhizal symbiosis enhances the photosynthetic efficiency and the antioxidative response of rice plants subjected to drought stress. J Plant Physiol. 2010;167:862-9.

94. Bresson J, Varoquaux F, Bontpart T, Touraine B, Vile D. The PGPR strain Phyllobacterium brassicacearum STM196 induces a reproductive delay and physiological changes that result in improved drought tolerance in Arabidopsis. New Phytol. 2013;200:558-69.

95. Mishra PK, Bisht SC, Jeevanandan K, Kumar S, Bisht JK, Bhatt JC. Synergistic effect of inoculating plant growth-promoting Pseudomonas spp. and Rhizobium leguminosarum-FB1 on growth and nutrient uptake of rajmah (Phaseolus vulgaris L.). Arch Agron Soil Sci. 2014;60:799-815.

96. Elkoca E, Turan M, Donmez MF. Effects of single, dual and triple inoculations with Bacillus subtilis, Bacillus megaterium and Rhizobium leguminosarum bv. phaseoli on nodulation, nutrient uptake, yield and yield parameters of common bean (Phaseolus vulgaris L. cv. 'Elkoca-05'). J Plant Nutr. 2010;33: 2104-19.

97. Badar R, Qureshi SA. Utilization of composted agricultural waste as organic fertilizer for the growth promotion of sunflower plants. J Pharmacogn Phytochem. 2015;3:184-7.

98. Prasad AA, Babu S. Compatibility of Azospirillum brasilense and Pseudomonas fluorescens in growth promotion of groundnut (Arachis hypogea L.). An Acad Bras Cienc. 2017;89:1027-40.

99. Jacob S, Sajjalaguddam RR, Kumar KVK, Varshney R, Sudini HK. Assessing the prospects of Streptomyces sp. RP1A-12 in managing groundnut stem rot disease caused by Sclerotium rolfsii Sacc. J Gen Plant Pathol. 2016;82:96-104.

100. Siddiqui Y, Meon S, Ismail R, Rahmani M, Ali A. Bio-efficiency of compost extracts on the wet rot incidence, morphological and physiological growth of okra (Abelmoschus esculentus [(L.) Moench]). Sci Hortic. 2008;117:9-14.

101. Afzal S, Tariq S, Sultana V, Ara J, Ehteshamul-Haque S. Managing the root diseases of okra with endo-root plant growth promoting Pseudomonas and Trichoderma viride associated with healthy okra roots. Pak J Bot. 2013;45:1455-60.

102. Maqbool Z, Asghar HN, Shahzad T, Hussain S, Riaz M, Afi S, et al. Isolating, screening and applying chromium reducing bacteria to promote growth and yield of okra (Hibiscus esculentus L.) in chromium contaminated soils. Ecotox Environ Safe. 2015;114:343-9.

103. Serna-Saldivar SO. Cereal grains: properties, processing, and nutritional attributes. Boca Raton: CRC Press; 2016.

104. Bouman BAM, Humphreys E, Tuong TP, Barker R. Rice and water. Adv Agron. 2007:92:187-237.

105. Karim MR, Rahman MA. Drought risk management for increased cereal production in Asian least developed countries. Weather Clim Extreme. 2015;7:24-35

106. Ortiz N, Armada E, Duque E, Roldan A, Azcon R. Contribution of arbuscular mycorrhizal fungi and/or bacteria to enhancing plant drought tolerance under natural soil conditions: effectiveness of autochthonous or allochthonous strains. J Plant Physiol. 2015;174:87-96.

107. Watanarojanaporn N, Boonkerd N, Tittabutr P, Longtonglang A, Young JPW, Teaumroong $\mathrm{N}$. Effect of rice cultivation systems on indigenous arbuscular mycorrhizal fungal community structure. Microbes Environ. 2013;28:316-24.

108. Rapparini F, Penuelas J. Mycorrhizal fungi to alleviate drought stress on plant growth. In: Miransari M, editor. Use of microbes for the alleviation of soil stresses, vol. 1. New York: Springer; 2014. p. 21-42.

109. Bharti N, Sharma SK, Saini S, Verma A, Nimonkar Y, Prakash O. Microbial plant probiotics: problems in application and formulation. In: Kumar V, Kumar M, Sharma S, Prasad R, editors. Probiotics and plant health. Singapore: Springer; 2017. p. 317-35.

110. Ruiz-Sanchez M, Armada E, Munoz Y, de Salamone IEG, Aroca R, RuizLozano JM, et al. Azospirillum and arbuscular mycorrhizal colonization enhance rice growth and physiological traits under well-watered and drought conditions. J Plant Physiol. 2011;168:1031-7.

111. Rai SK, Charak D, Bharat R. Scenario of oilseed crops across the globe. Plant Arch. 2016;16:125-32.

112. Javaid A, Mahmood N. Growth, nodulation and yield response of soybean to biofertilizers and organic manures. Pak J Bot. 2010;42:863-71. 
113. Aetiba JPN, Osekre EA. Field evaluation of levo botanical insecticide for the management of insect pests of eggplant (Solanum melongena L.). Aust Exp Agric. 2015;8:61-7.

114. Asare-Bediako E, Agyarko F, Verbeek M, Taah KJ, Asare A, Agyei FK, et al. Variation in the susceptibility of okra (Abelmoschus esculentus L. Moench) genotypes to okra mosaic virus and Podagrica species under field conditions. J Plant Breed Crop Sci. 2017;9:79-89.

\section{Publisher's Note}

Springer Nature remains neutral with regard to jurisdictional claims in published maps and institutional affiliations.

Ready to submit your research? Choose BMC and benefit from:

- fast, convenient online submission

- thorough peer review by experienced researchers in your field

- rapid publication on acceptance

- support for research data, including large and complex data types

- gold Open Access which fosters wider collaboration and increased citations

- maximum visibility for your research: over $100 \mathrm{M}$ website views per year

At BMC, research is always in progress.

Learn more biomedcentral.com/submissions 